\title{
Chemical and Biological Assessments of the Essential Oils of Chrysophyllum albidum G. Don
}

\author{
Fatimah Temitayo Ishola ${ }^{1}$, Sherifat Adeyinka Aboaba ${ }^{1}$, Muhammad Iqbal Choudhary ${ }^{2}$ and Olusegun Ekundayo ${ }^{1}$ \\ 1. Department of Chemistry, University of Ibadan, Ibadan-200284, Nigeria \\ 2. Hussain Ebrahim Jamal Research Institute of Chemistry, International Center for Chemical and Biological Sciences, University of \\ Karachi, Karachi-75270, Pakistan
}

\begin{abstract}
The chemical compositions of the essential oils obtained from six tree parts of Chrysophyllum albidum (Sapotaceae) were extracted by hydrodistillation and analyzed by gas chromatography (GC) and gas chromatography-mass spectrometry (GC-MS). A total of $65,33,45,21,25$ and 18 compounds, representing $79.49 \%, 100 \%, 90.81 \%, 98.43 \%, 96.62 \%$ and $98.37 \%$ of the total oil, were identified in the fruit bark, root bark, stem bark, seed bark, leaf and seed, respectively. The dominant compounds in the essential oils in six tree parts were m-xylene (66.7\%; seed), p-xylene (21.4\%; seed bark), $\alpha$-farnesene (38.1\%; leaf), hexadecanoic acid (14.7\%; stem bark), m-xylene (53.1\%; root bark) and hexadecanoic acid (12.7\%; fruit bark). The essential oils were evaluated for their antibacterial, antioxidant and insecticidal activities using Alamar blue assay, DPPH radical scavenging activity and contact toxicity test, respectively. The oils displayed moderate antibacterial potentials to some tested organisms and low radical scavenging activity to DPPH. Rhyzopertha dominica was susceptible to C. albidum stem bark essential oil only.
\end{abstract}

Key words: Chrysophyllum albidum, essential oil, gas chromatography, antioxidant activity, insecticidal activity, Alamar blue assay.

\section{Introduction}

Essential oils are volatile, natural complex compounds characterized by a strong odour, and are also promising sources of natural medicinal products because of the bioactive components they possess [1]. Pharmacologically, essential oils have been used as insect repellent, insecticide, antimicrobial, antioxidant, pesticide and deodorants; therefore, the possibility of using essential oils is now being investigated as the basis of the plant-based drugs [2].

African star apple (Chrysophyllum albidum G. Don) is a tropical edible fruit tree. It belongs to the family of Sapotaceae which has up to 800 species and makes up almost half of the order [3]. It is primarily a forest tree species, and its natural occurrence has been reported in diverse ecozones in Nigeria, Uganda, Niger Republic, Cameroon and Cote d'Ivoire [4]. The plant often grows to a height of $36 \mathrm{~m}$, though it may

Corresponding author: Sherifat Adeyinka Aboaba, Ph.D., research fields: natural products and organic chemsitry. be smaller [5]. The African star apple fruit is a large berry containing 4-5 flattered seeds or sometimes fewer due to seed abortion. The leaves are oval, green above, densely golden pubescent, below from which the genus is named. The plant has in recent times become a crop of commercial value in Nigeria [6].

The fruit is commonly found in the Central, Eastern and Western Africa. It is a popular tropical fruit tree widely distributed in the low land rain forest zones and frequently found in villages [7]. It has common names known as agbalumo (Yoruba), udala (Igbo), agbaluba (Hausa) and eha (Ebira) in the local languages in Nigeria [8]. C. albidum fruit is common in both urban and rural centres especially during the months of December to April.

C. albidum is widely used as an application to sprains, bruises and wounds in herbal medicine in Southern Nigeria. The seeds and roots extracts of $C$. albidium effectively arrested bleeding from fresh wounds, inhibited microbial growth of known wound contaminants and accelerated wound healing process 
[7]. The people of Southwestern Nigeria have been using C. albidum leaves for the management of infections and ailments since prehistoric times [9]. In addition, its seeds are a source of oil, which is used for diverse purposes [10]. C. albidum is used in folklore in the treatment of yellow fever, malaria, diarrhea, vaginal and dermatological infections [11]. The bark is used for the treatment of malaria and yellow fever [11], while the leaf is used as an emollient and for the treatment of skin eruption, stomachache and diarrhea [12] which are as a result of infections and inflammatory reactions [12, 13]. The leaf extract of C. albidum can help to thin the blood (antiplatelet effect), as well as regulate the sugar level in blood sugar [14]. C. albidum is established to have haematinic potentials [15]. The fruits also contain $90 \%$ anacardic acid, which is used industrially in protecting wood and as source of resin, while several other components of the tree including the roots and leaves are used as a remedy for yellow fever and malaria [9]. The cotyledons from the seeds of C. albidum are used as ointments in the treatment of vaginal and dermatological infections in Western Nigeria. The seeds are also used for local games or discarded [4].

C. albidum is good for the treatment of fibroids as reported by Egunyomi and Oladunjoye [16]. When freshly harvested, the fleshy and juicy fruits have potentials as an ingredient of soft drinks and can be fermented for wine or other alcohol production [17].

Earlier report on the essential oil composition of $C$. albidum fruit revealed eight compounds accounting for $90.8 \%$ of total components with esters (65.1\%) constituting the most abundant class of compounds [18], while the root essential oil had 24 compounds with a phthalate (dibutyl-1,2-benzenedicarboxylate) being the major identified constituent [19].

There is dearth of information about the essential oil composition of the leaf, stem bark, fruit bark, seed, seed bark and root bark of C. albidum, therefore this paper aimed primarily to investigate the chemical composition and biological activities of essential oils of C. albidum G. Don.

\section{Materials and Methods}

\subsection{Plant Samples}

Fresh plant parts (leaves, stem bark, root bark, fruit bark, seed and seed bark) of C. albidum were collected from a farm settlement located at the outskirts of Ibadan in Egbeda local government and authenticated at Forest Research Institute of Nigeria (FRIN) by Mr. Adeyemo. Voucher specimens were duly deposited in the FRIN herbarium with reference number FHI 110499.

\subsection{Essential Oil Extraction}

Fresh matured leaves, stem bark, root bark, fruit bark, seed and seed bark (500-1,000 g) of C. albidum tree were air-dried and subjected to hydrodistillation using an all-glass Clevenger-apparatus designed to the British pharmacopeia specifications (1980) for $4 \mathrm{~h}$ using a $5 \mathrm{~L}$ quick fit round bottom flask. The oils were dried in desiccators containing anhydrous sodium sulphate $\left(\mathrm{Na}_{2} \mathrm{SO}_{4}\right)$ for $24 \mathrm{~h}$ and then stored in airtight containers in a refrigerator at $4{ }^{\circ} \mathrm{C}$. The yields were calculated according to the weight of the plant material before distillation (expressed in percentage $\mathrm{w} / \mathrm{w}$ of the dry material).

\subsection{Gas Chromatography (GC)}

The oil was analyzed on an Agilent Model 7890A GC equipped with a HP-5MS fused silica capillary column $(30 \mathrm{~mm} \times 0.25 \mathrm{~mm}$ internal diameter, film thickness $0.25 \mu \mathrm{m})$. Analytical conditions were: oven temperature at $60{ }^{\circ} \mathrm{C}$, with $2 \mathrm{~min}$ initial hold, and then to $280{ }^{\circ} \mathrm{C}$ at $4{ }^{\circ} \mathrm{C} / \mathrm{min}$, with final hold time of $10 \mathrm{~min}$; helium was used as carrier gas at a flow rate of 1 $\mathrm{mL} / \mathrm{min}$. Retention indices were determined with reference to a homologous series of normal alkanes analyzed under the same conditions. Percentage composition of each constituent was calculated by integration of the GC peak areas. 


\subsection{Gas Chromatography-Mass Spectrometry (GC-MS)}

GC-MS analyses were performed on an Agilent Model 7890A GC interfaced to an Agilent 7000 GC/MS Triple Quad. The temperature program used for the GC was the same as described above. The MS was operated in electron ionization (EI) mode with ionization voltage $70 \mathrm{eV}$ and ion source temperature $250{ }^{\circ} \mathrm{C}$.

\subsection{Components Identification}

The components of the essential oil were identified on the basis of their retention indices. Identification confirmation was by comparison of their mass spectra with published spectra $[20,21]$ and those of reference compounds from the Library of National Institute of Standard and Technology (NIST) database [22].

\subsection{Antibacterial Screening}

The essential oil was screened for antimicrobial activities on selected Gram-positive bacteria (Staphylococcus aureus and Bacillus subtilis) and Gram-negative bacteria (Escherichia coli, Pseudomonas aeruginosa, Shigella flexineri and Salmonella typhi) known as causative agents for various infectious diseases. Microplate Alamar blue assay was used to determine minimum inhibitory concentration (MIC). Organisms were grown in Mueller Hinton medium and inoculums were adjusted to 0.5 McFarland turbidity index. Stock solutions of the essential oils were prepared in DMSO (1:1 concentration). Media was dispensed to all wells. Essential oils were added in the wells, and control wells not contain essential oil. The volume of 96-well plate was made up to $200 \mu \mathrm{L}$. Finally, $5 \times 10^{6}$ cells were added in all wells including both control and test. The plate was sealed with parafilm and incubated for 18-20 h. Alamar blue dye was dispensed in each well and shaken at 80 revolutions per minute in a shaking incubator for 2-3 $\mathrm{h}$. Plates were covered with foil in shaking incubator. Change in color of Alamar blue dye from blue to pink indicated the growth in bacterial strains. Absorbance was recorded at $570 \mathrm{~nm}$ and $600 \mathrm{~nm}$ by the ELISA reader (SpectraMax M2, Molecular Devices, California, USA). All work was done in triplicate.

2.7 Antioxidant Activity: DPPH Radical Scavenging Activity

Radical scavenging activity was determined by a spectrophotometric method based on the reduction of a methanol solution of DPPH [23]. DPPH (Wako Chemicals USA, Inc.) solution in methanol was prepared to make $0.3 \mathrm{mM}$, then $1 \mathrm{~mL}$ of essential oil was added to $1 \mathrm{~mL}$ of $0.3 \mathrm{mM}$ DPPH solution and shaken vigorously. The reaction was allowed to progress for $30 \mathrm{~min}$ at $37{ }^{\circ} \mathrm{C}$ in the dark, and absorbance was monitored and recorded as $A_{S}$, using multiplate reader, SpectraMax340, Molecular Devices, CA, USA at $517 \mathrm{~nm}$. Upon reduction, the color of the solution fades (violet to pale yellow). A control experiment was also carried out applying the same procedure to a solution without the test material and the absorbance was recorded as $A_{C}$. The free radical scavenging activity of each solution was then calculated as percent inhibition according to Eq. (1):

$$
\text { Radical scavenging activity }(\%)=\frac{A_{C}-A_{S}}{A_{C}} \times 100
$$

where, $A_{C}=$ absorbance of the control and $A_{S}=$ absorbance of the sample.

\subsection{Insecticidal Activity}

The insecticidal activity was conducted according to the impregnated filter paper method (contact toxicity) [24].

The stored grain pests Tribolium castaneum, Rhyzopertha dominica and Callosobruchus analis were reared in the laboratory under controlled conditions (temperature and humidity) in plastic bottles containing sterile breeding media, as shown in Table 1. Then, insects of uniform age and size are used for the experiment. 
The filter papers were cut according to the size of glass Petri plates $(9 \mathrm{~cm}$ or $90 \mathrm{~mm})$ and put in the plates. Essential oils were loaded over the filter paper in the plates with the help of micropipette. Ten healthy and active insects of same size and age of each species were put in each plate (test and control) with the help of a clean brush. The plates were incubated at $27^{\circ} \mathrm{C}$ for $24 \mathrm{~h}$ with $50 \%$ relative humidity in growth chamber. The survival of the insects was assessed (count the number of survivals of each species).

The percentage of inhibition or percentage of mortality was calculated using Eq. (2) below:

$$
\begin{gathered}
\text { Mortality }(\%)= \\
1-\frac{\text { No. of insects alive in test }}{\text { No. of insects alive in control }} \times 100
\end{gathered}
$$

Positive control contained test insects and standard insecticide (Permethrin) at the concentration which is effective against all test insects. Negative control contained volatile solvent (methanol) and the test insects.

\section{Results and Discussion}

\subsection{Physicochemical Properties and Components of} the Essential Oils

The physicochemical properties of the essential oils are shown in Table 2. The colours of the oils ranged from colourless to pale yellow with the yields as follows: leaf $(0.89 \%)$, seed $(0.91 \%)$, seed bark $(0.13 \%)$, stem bark $(0.86 \%)$, root bark $(1.21 \%)$ and fruit bark $(0.95 \%)$. All the fruits have sweet aromatic and fruity smell, which has been reported due to the presence of esters, aldehydes, alcohols, terpenes or their derivatives, but the oils of the root bark and stem barks have irritating woody smell, while the leaves have a strong leafy odour.

The GC-MS analyses of the essential oils of the fruit bark, root bark, stem bark, seed bark, leaf and seed of C. albidium afforded the presence of 65,33 , 45, 21, 25 and 18 compounds constituting 79.49\%, $100 \%, 90.81 \%, 98.43 \%, 96.62 \%$ and $98.37 \%$ of the oil compositions in the six different parts, respectively (Table 3). Monoterpenes and sesquiterpenes were present in all the oils. The root bark oil had the highest percentage of monoterpene $(8.5 \%)$, while the fruit bark oil had the least $(1.19 \%)$. The leaf oil had the highest percentage of sesquiterpenes $(75.67 \%)$ and the seed bark oil had the lowest quantity (1.3\%). Diterpenes were not present in all the oils, while triterpenes were observed in only the fruit bark and oils, except the seed oil. The root bark, seed bark and seed oils had $66.9 \%, 94.24 \%$ and $91.15 \%$ non-terpene

Table 1 Insects and rearing conditions.

\begin{tabular}{lllll}
\hline Insects & Rearing temperature $\left({ }^{\circ} \mathrm{C}\right)$ & Relative humidity $(\%)$ & Rearing media & Life cycle (days) \\
\hline $\begin{array}{l}\text { Red flour beetle } \\
\begin{array}{l}\text { (Tribolium castaneum) } \\
\text { Lesser grain borer }\end{array}\end{array}$ & 30 & $50-70$ & Wheat flour & $22-25$ \\
$\begin{array}{l}\text { Rhyzopertha dominica) } \\
\begin{array}{l}\text { Pulse beetle } \\
\text { (Callosobruchus analis) }\end{array}\end{array}$ & $25-35$ & $50-70$ & Wheat and gram seeds & 30 \\
\hline
\end{tabular}

Table 2 Physicochemical properties of essential oils.

\begin{tabular}{lllll}
\hline Plant sample & Part used & \% extract composition & Colour & Odour \\
\hline \multirow{4}{*}{ C. albidum } & Stem bark & 0.86 & Colourless & Woody \\
& Root bark & 1.21 & Colourless & Woody \\
& Leaf & 0.89 & Pale yellow & Leafy \\
& Seed & 0.91 & Colourless & Sweet aromatic \\
& Seed bark & 0.13 & Colourless & Herbal \\
& Fruit bark & 0.95 & Pale yellow & Fruity \\
\hline
\end{tabular}


Chrysophyllum albidum G. Don

Table 3 Essential oil components from plant parts of $C$. albidum.

\begin{tabular}{|c|c|c|c|c|c|c|c|c|}
\hline \multirow{2}{*}{ No. } & \multirow{2}{*}{ Compound name } & \multirow{2}{*}{ RI } & \multicolumn{6}{|c|}{ Yield of compounds in essential oil (\%) } \\
\hline & & & Fruit bark & Root bark & Stem bark & Seed bark & Leaf & Seed \\
\hline 1 & Methylcyclohexane & 781 & 0.14 & - & 1.30 & - & - & - \\
\hline 2 & Toluene & 794 & 1.22 & - & 3.08 & - & - & - \\
\hline 3 & 3,5-dimethyloctane & 887 & - & 1.36 & - & - & - & 1.52 \\
\hline 4 & Ethylbenzene & 893 & 0.09 & 9.41 & 0.23 & 4.40 & - & - \\
\hline 5 & m-xylene & 907 & 0.37 & 53.11 & 0.81 & - & - & 66.72 \\
\hline 6 & o-xylene & 907 & - & - & 0.25 & - & - & - \\
\hline 7 & p-xylene & 907 & 0.16 & - & - & 21.38 & 5.15 & 3.02 \\
\hline 8 & Nonane & 916 & 0.08 & - & - & - & - & - \\
\hline 9 & Cumene & 928 & - & 0.83 & - & - & - & - \\
\hline 10 & (-) $\beta$-pinene & 943 & 0.07 & 0.52 & - & - & - & - \\
\hline 11 & 1R- $\alpha$-pinene & 948 & 0.06 & - & - & 0.34 & - & - \\
\hline 12 & S-3-carene & 948 & - & 0.31 & - & - & - & - \\
\hline 13 & 2,3,6,7-tetramethyloctane & 958 & - & - & - & - & - & 0.82 \\
\hline 14 & 4,5-dimethylnonane & 986 & - & - & - & - & - & 1.27 \\
\hline 15 & $\alpha$-decene & 1,005 & - & - & - & - & - & 1.09 \\
\hline 16 & m-ethyltoluene & 1,006 & 0.09 & 0.45 & 0.13 & - & - & - \\
\hline 17 & Decane & 1,015 & 0.08 & 1.24 & - & - & - & 1.05 \\
\hline 18 & D-limonene & 1,018 & 0.03 & 0.95 & - & 0.42 & - & 1.55 \\
\hline 19 & Trimethylbenzene & 1,020 & 0.09 & - & - & - & - & - \\
\hline 20 & Hemimelitene & 1,021 & - & 3.44 & - & - & - & - \\
\hline 21 & $\beta$-cymene & 1,042 & - & 0.56 & - & - & - & - \\
\hline 22 & $\alpha$-terpinolene & 1,052 & - & 0.63 & - & - & - & 1.77 \\
\hline 23 & 1,8 -cineole & 1,059 & - & 0.78 & - & - & - & - \\
\hline 24 & $\beta$-linalool & 1,082 & 0.56 & 0.48 & 0.77 & - & 1.33 & - \\
\hline 25 & Nonanal & 1,104 & 0.15 & 0.47 & 0.45 & 0.61 & 1.65 & - \\
\hline 26 & Undecane & 1,115 & - & - & - & - & 0.45 & 7.16 \\
\hline 27 & Cyclosativene & 1,125 & - & - & 0.14 & - & - & - \\
\hline 28 & (-) $\alpha$-terpineol & 1,143 & 0.11 & - & - & - & - & - \\
\hline 29 & 2,3,5,8-tetramethyldecane & 1,156 & - & - & - & 0.42 & - & - \\
\hline 30 & Indole & 1,174 & 0.18 & - & 0.74 & - & - & - \\
\hline 31 & Cis-carvotanacetol & 1,175 & - & - & - & 1.21 & - & - \\
\hline 32 & Methylnonanoate & 1,183 & - & 0.45 & - & - & - & - \\
\hline 33 & Decanal & 1,204 & 0.09 & - & 0.27 & - & - & - \\
\hline 34 & Dodecane & 1,215 & - & - & - & - & - & 0.73 \\
\hline 35 & (-) $\alpha$-copaene & 1,221 & 0.13 & - & 0.67 & - & 0.57 & - \\
\hline 36 & Cis-geraniol & 1,228 & 0.06 & - & - & - & - & - \\
\hline 37 & Isoaromadendrene epoxide & 1,281 & 0.17 & - & - & - & - & - \\
\hline 38 & 4,6-dimethyldodecane & 1,285 & - & 0.41 & - & - & - & 2.87 \\
\hline 39 & Calarene epoxide & 1,293 & 0.04 & - & - & - & - & - \\
\hline 40 & Undecanal & 1,303 & - & - & - & - & 3.63 & - \\
\hline 41 & $\alpha$-tridecene & 1,304 & - & - & - & - & - & 1.79 \\
\hline 42 & 2,6,11-trimethyldodecane & 1,320 & - & - & - & - & - & 1.01 \\
\hline 43 & $(-) \alpha$-cubebene & 1,344 & - & 0.72 & - & - & - & - \\
\hline 44 & Aromadendrene & 1,386 & 0.49 & - & - & - & - & - \\
\hline 45 & 3-hexenylhexanoate & 1,389 & - & - & - & - & 1.12 & - \\
\hline 46 & (-) $\beta$-elemene & 1,398 & 6.74 & 4.74 & 12.71 & - & 7.81 & - \\
\hline 47 & $\alpha$-cedrene & 1,403 & 0.83 & 1.23 & - & - & 1.58 & - \\
\hline
\end{tabular}


(Table 3 continued)

\begin{tabular}{|c|c|c|c|c|c|c|c|c|}
\hline \multirow{2}{*}{ No. } & \multirow{2}{*}{ Compound name } & \multirow{2}{*}{ RI } & \multicolumn{6}{|c|}{ Yield of compounds in essential oil (\%) } \\
\hline & & & Fruit bark & Root bark & Stem bark & Seed bark & Leaf & Seed \\
\hline 48 & $(+) \alpha$-longipinene & 1,403 & 0.09 & - & 0.12 & - & - & - \\
\hline 49 & $\alpha$-patchoulene & 1,405 & 0.38 & - & 0.54 & - & - & - \\
\hline 50 & $\alpha$-gurjunene & 1,419 & 0.58 & - & 1.38 & - & 1.02 & - \\
\hline 51 & Geranyl acetone & 1,420 & 0.12 & - & 0.24 & - & - & - \\
\hline 52 & $\alpha$-ionone & 1,429 & - & - & - & - & 0.69 & - \\
\hline 53 & $\beta$-bergamotene & 1,430 & 0.06 & - & - & - & - & - \\
\hline 54 & $\alpha$-bergamotene & 1,432 & - & 2.01 & 0.19 & - & 0.92 & - \\
\hline 55 & $\gamma$-cadinene & 1,435 & 0.05 & - & - & - & - & - \\
\hline 56 & Cyclohexylhexanoate & 1,445 & - & - & - & - & 0.68 & - \\
\hline 57 & $\beta$-sesquiphellandrene & 1,446 & 0.38 & - & 0.51 & - & - & - \\
\hline 58 & $\alpha$-farnesene & 1,458 & - & - & - & - & 38.11 & 0.88 \\
\hline 59 & $\beta$-selinene & 1,469 & 3.32 & 1.15 & 4.15 & - & - & - \\
\hline 60 & $(+) \delta$-cadinene & 1,470 & - & - & 0.32 & - & - & - \\
\hline 61 & $\alpha$-selinene & 1,474 & 2.11 & 2.13 & 3.01 & - & 5.11 & 3.02 \\
\hline 62 & Acoradiene & 1,476 & - & 0.43 & 0.69 & - & - & - \\
\hline 63 & $\beta$-caryophyllene & 1,494 & 1.69 & 2.93 & 4.91 & 0.37 & 8.54 & - \\
\hline 64 & $\alpha$-himachalene & 1,497 & 0.41 & - & 0.51 & - & - & - \\
\hline 65 & $( \pm) \beta$-bisabolene & 1,500 & 1.45 & 2.67 & 1.42 & - & - & - \\
\hline 66 & $\beta$-caryophyllene oxide & 1,507 & 1.99 & - & 0.85 & - & 2.14 & - \\
\hline 67 & Cis- $\alpha$-bisabolene & 1,518 & - & 0.37 & - & - & - & - \\
\hline 68 & 2,6,10-trimethyltetradecane & 1,519 & - & - & - & 0.86 & - & - \\
\hline 69 & $\alpha$-curcumene & 1,524 & 2.56 & 0.75 & 3.48 & - & - & - \\
\hline 70 & $\beta$-himachalene & 1,528 & - & 0.71 & 0.13 & - & 0.63 & - \\
\hline 71 & Palustrol & 1,529 & 0.29 & - & - & - & - & - \\
\hline 72 & Epiglobulol & 1,530 & 1.24 & - & 0.87 & - & - & - \\
\hline 73 & Globulol & 1,530 & 0.52 & - & 0.36 & - & 1.31 & - \\
\hline 74 & $(+)$ Ledol & 1,530 & - & - & - & - & 1.56 & - \\
\hline 75 & Veridiflorol & 1,530 & - & - & - & 0.45 & - & - \\
\hline 76 & $\alpha$-bisabolene oxide & 1,531 & 0.23 & - & - & - & - & - \\
\hline 77 & Isomethyl- $\alpha$-ionol & 1,532 & 0.12 & - & - & - & - & - \\
\hline 78 & (-)Calamenene & 1,537 & 0.48 & - & - & - & - & - \\
\hline 79 & Limonen-6-ol pivalate & 1,560 & 0.11 & - & - & - & - & - \\
\hline 80 & Hexahydrofarnesol & 1,563 & - & - & 0.39 & - & - & - \\
\hline 81 & Trans nerolidol & 1,564 & 0.21 & - & - & - & 2.35 & - \\
\hline 82 & Dodecanoic acid & 1,570 & 1.83 & - & 1.79 & - & - & - \\
\hline 83 & $\gamma$-elemene & 1,573 & - & - & - & 0.48 & - & - \\
\hline 84 & $\alpha$-caryophyllene & 1,579 & 1.15 & 0.62 & 2.13 & - & 3.11 & - \\
\hline 85 & Cubenol & 1,580 & 0.78 & - & 0.76 & - & - & - \\
\hline 86 & Tau-cadinol & 1,582 & 0.5 & - & 0.47 & - & - & - \\
\hline 87 & Dendrolasin & 1,607 & - & - & - & - & 0.91 & - \\
\hline 88 & $\beta$-bisabolol & 1,619 & 3.44 & 2.79 & 5.52 & - & - & - \\
\hline 89 & $\alpha$-bisabolol & 1,625 & 0.54 & - & 1.32 & - & - & - \\
\hline 90 & Selin-7(11)-en-4 $\alpha$-ol & 1,647 & 11.42 & 0.9 & 6.32 & - & - & - \\
\hline 91 & 8-heptadecene & 1,719 & - & - & - & - & 2.71 & - \\
\hline 92 & Hexahydrofarnesylacetone & 1,754 & 0.52 & 0.45 & 0.35 & 0.92 & 3.54 & - \\
\hline 93 & Tetradecanoic acid & 1,769 & 4.06 & - & 2.17 & - & - & - \\
\hline 94 & Isopropyltetradecanoate & 1,814 & - & - & - & 3.08 & - & - \\
\hline
\end{tabular}


(Table 3 continued)

\begin{tabular}{|c|c|c|c|c|c|c|c|c|}
\hline \multirow{2}{*}{ No. } & \multirow{2}{*}{ Compound name } & \multirow{2}{*}{ RI } & \multicolumn{6}{|c|}{ Yield of compounds in essential oil (\%) } \\
\hline & & & Fruit bark & Root bark & Stem bark & Seed bark & Leaf & Seed \\
\hline 95 & 5-octadecene & 1,818 & - & - & - & - & - & 0.68 \\
\hline 96 & Hexadecanol & 1,854 & 1.23 & - & 1.91 & - & - & - \\
\hline 97 & Pentadecanoic acid & 1,869 & 1.81 & - & 1.27 & - & - & - \\
\hline 98 & Nonadecane & 1,910 & - & - & - & 2.21 & - & - \\
\hline 99 & Heptadecanol & 1,954 & 0.72 & - & - & - & - & - \\
\hline 100 & Hexadecanoic acid & 1,968 & 12.73 & - & 14.09 & - & - & - \\
\hline 101 & 9-hexadecenoic acid & 1,976 & 1.6 & - & - & - & - & - \\
\hline 102 & Ethylhexadecanoate & 1,978 & - & - & - & 19.94 & - & 1.42 \\
\hline 103 & Octadecanol & 2,053 & - & - & 5.91 & - & - & - \\
\hline 104 & Heneicosane & 2,109 & - & - & - & 3.01 & - & - \\
\hline 105 & Ethyloctadecanoate & 2,177 & - & - & - & 0.51 & - & - \\
\hline 106 & Cis,cis-9,12-octadecadienoic acid & 2,183 & 1.12 & - & - & - & - & - \\
\hline 107 & Ethyl-9-octadecenoate & 2,185 & - & - & - & 5.21 & - & - \\
\hline 108 & Ethyl-9,12-octadecadienoate & 2,193 & - & - & - & 16.91 & - & - \\
\hline 109 & Heptacosane & 2,705 & - & - & - & 10.51 & - & - \\
\hline 110 & $\alpha$-Amyrin & 2,873 & 1.05 & - & - & - & - & - \\
\hline 111 & Squalene & 2,914 & 1.44 & - & 1.18 & - & - & - \\
\hline 112 & Lupenyl acetate & 2,987 & 2.94 & - & - & - & - & - \\
\hline 113 & $\begin{array}{l}\text { 2,2-methylene bis } \\
{[6 \text {-(1,1-dimethylethyl) 4-ethyl }]} \\
\text { phenol }\end{array}$ & 2,988 & - & - & - & 5.19 & - & - \\
\hline 114 & Heptatriacotanol & 3,942 & 0.19 & - & - & - & - & - \\
\hline \multicolumn{3}{|c|}{ No. of compounds } & 65 & 33 & 45 & 19 & 23 & 17 \\
\hline \multicolumn{3}{|c|}{ Total yield } & 79.49 & 100 & 90.81 & 98.43 & 96.62 & 98.37 \\
\hline \multicolumn{3}{|c|}{ Monoterpenes } & 1.19 & 8.50 & 1.65 & 1.97 & 1.33 & 3.32 \\
\hline \multicolumn{3}{|c|}{ Sesquiterpenes } & 44.56 & 24.15 & 53.58 & 1.3 & 75.67 & 3.90 \\
\hline \multicolumn{3}{|c|}{ Triterpenes } & 5.43 & - & 1.18 & - & - & - \\
\hline \multicolumn{3}{|c|}{ Apocarotenes } & 0.64 & 0.45 & 0.74 & 0.92 & 4.23 & - \\
\hline \multicolumn{3}{|c|}{ Non-terpenes } & 27.67 & 66.90 & 33.66 & 94.24 & 15.39 & 91.15 \\
\hline
\end{tabular}

RI: retention index.

compounds, respectively. All other samples had less than $35 \%$ of their components as non-terpenes.

The major compounds in the fruit bark oil were hexadecanoic acid (12.73\%), selin-7(11)-en-4 $\alpha$-ol (11.42\%), $\beta$-elemene (6.74\%) and $\beta$-bisabolol (3.44\%), while the root bark oil was dominated by m-xylene (53.11\%), ethylbenzene $(9.41 \%)$ and $\beta$-elemene (4.74\%). Hexadecanoic acid (14.09\%), $\beta$-elemene (12.71\%), selin-7(11)-en-4 $\alpha$-ol $\quad(6.32 \%) \quad$ and $\beta$-bisabolol (5.52\%) were the dominant compounds in the stem bark oil, while the seed bark oil was dominated by p-xylene (21.38\%), ethylhexadecanoate (19.94\%), ethyl-9,12-octadecadienoate (16.91\%) and heptacosane $(10.51 \%)$. In the leaf oil, $\alpha$-farnesene
(38.11\%), $\quad \beta$-caryophyllene $\quad(8.54 \%), \quad \beta$-elemene (7.81\%), p-xylene $(5.15 \%)$ and $\alpha$-selinene $(5.11 \%)$ were the major constituents, but m-xylene (66.72\%) and undecane $(7.16 \%)$ dominated the seed oil.

Moronkola et al. [19] reported 24 compounds in the root essential oil of C. albidum G. Don with monoterpenes $(40.5 \%)$ and sesquiterpenes $(27.9 \%)$ as the dominant class of compounds with pinene (34\%), caryophyllene (12.8\%), isocaryophyllene $(8.5 \%)$ and 1,8 -cineole $(6.5 \%)$ as the major compounds. However, the report does not agree with the result of this study. Non-terpenes (66.9\%) and sesquiterpenes (24.15\%) were found to be dominant with m-xylene and $\beta$-elemene as the major compounds in the class of 
compounds, respectively. $\beta$-pinene was present in the oil in low quantity. Earlier report by Moronkola [18] on the essential oil of the fruit presented eight compounds accounting for $90.8 \%$ of total components with esters $(65.1 \%)$ constituting the most abundant class of compounds. A phthalate (dibutyl-1,2-benzenedicarboxylate) was the major compound. The fruit bark analyzed in this study however contained more sesquiterpenes (44.56\%). The compositional pattern of the essential oils from the leaf, stem bark, seed, seed bark and fruit bark of $C$. albidum is being reported for the first time to the best of knowledge.

\subsection{Antibacterial Activity of Essential Oils}

The essential oils extracted from six parts of $C$. albidum were also screened against the selected bacteria. The study revealed the non-active nature of the essential oil from the seed against all the test bacteria strains, except Staphylococcus aureus with $70.585 \%$. Escherichia coli strain was resistant to all the essential oils from the different parts of this fruit tree, but Shigella flexenari was susceptible to all the volatile oils, except the seed essential oil. Pseudomonas aeruginosa and Salmonella typhi strains were resistant to all the oils, except the seed bark $(10.191 \%)$ and root bark $(9.787 \%)$ oils, respectively (Table 4).

\subsection{Insecticidal Property of Essential Oils}

All the oils showed no toxicity ( $0 \%$ mortality) against the insects, except for C. albidium stem bark with $20 \%$ mortality against Rhyzopertha dominica.
The insects were observed to be resistant to the oils used for this study based on the impregnated filter paper method, which is a form of contact toxicity. In contact toxicity, stomach poisoning occurs while the insects feed on the whole grains. The weevils have to pick up the lethal dose of treatment from the essential oil to cause toxicity.

Previous studies have shown that the toxicity of essential oils obtained from aromatic plants against storage pests is related to the oil's main components [25]. The insecticidal constituents of many plant extracts and essential oils are mainly monoterpenoids [26-29]. Monoterpenoids are typically volatile and rather lipophilic compounds that can penetrate into insects rapidly and interfere with their physiological functions [30]. Due to their high volatility, they are fumigant and gaseous, and might be of importance for stored-product insects [27]. Various monoterpenes, like 1,8-cineole, linalool, $\alpha$-pinene, terpinen-4-ol and $\alpha$-terpinene, have been reported to show contact and fumigation toxicity to stored product pests $[31,32]$. Therefore, the resistance of the essential oils studied for insecticidal activity may be related to the non-dominance of monoterpenes in the identified components in the oils.

The synergistic action between major and minor components of essential oils could also be responsible for the repellent action of the oils to the insects.

\subsection{Antioxidant Property of Essential Oils}

The six essential oil samples were screened using DPPH. The antioxidant activity of the volatile oils was measured in terms of hydrogen donating or

Table 4 Percentage inhibition of essential oils from C. albidum G. Don plant parts.

\begin{tabular}{llllllll}
\hline \multirow{2}{*}{ Bacteria } & \multicolumn{7}{c}{ Percentage inhibition of oils (\%) } \\
\cline { 2 - 8 } & Ampicillin & Fruit bark & Root bark & Stem bark & Seed bark & Leaf & Seed \\
\hline Escherichia coli & 72.000 & - & - & - & - & - & - \\
Bacillus subtilis & 76.000 & 8.662 & 28.387 & - & 15.942 & - & - \\
Shigella flexenari & 65.000 & 21.137 & 35.594 & 9.614 & 6.345 & 13.806 & - \\
Staphylococcus aureus & 79.000 & 16.409 & 10.478 & - & - & 6.803 & 70.585 \\
Pseudomonas aeruginosa & 80.000 & - & - & - & 10.191 & - & - \\
Salmonella typhi & 70.000 & - & 9.787 & - & - & - & - \\
\hline
\end{tabular}


Table 5 Percentage of radical scavenging activity of essential oils from C. albidum G. Don plant parts.

\begin{tabular}{ll}
\hline Plant materials & Radical scavenging activity (\%) \\
\hline Root bark & 3.28 \\
Stem bark & 3.22 \\
Seed bark & 2.69 \\
Fruit bark & 24.85 \\
Leaf & 6.20 \\
Seed & 7.52 \\
\hline Standard & \\
\hline Gallic acid & 93.13 \\
n-acetyl cystein & 95.95 \\
\hline
\end{tabular}

radical scavenging ability, using the stable radical DPPH. The percentage of radical scavenging ability of the volatile oils was calculated based on the absorbance measurement as shown in Table 5.

All oils from $C$. albidum had very low radical scavenging ability. The fruit bark oil recorded the highest value at $24.85 \%$, while the root bark, stem bark, seed bark, leaf and seed all had the percentage of radical scavenging ability low $10 \%$. The percentages of radical scavenging ability of all the essential oils were lower than that of the standards used for the study. The percentages of radical scavenging ability of gallic acid and n-acetyl cystein used as standards were $93.13 \%$ and $95.95 \%$, respectively.

The observed low radical scavenging ability of the essential oils can be explained by the fact that the oils are not capable of donating hydrogen atom, and by the low solubility provided by the oils in the reaction medium of the assay because this test utilizes methanol or ethanol as solvent as explained by a report by Mata et al. [33]. Viuda-Martos et al. [34] also cited these factors as the main limitation of this assay for measuring antioxidant activity of lipophilic samples, like many essential oils. Despite the essential oils tested in this study not showing significant antioxidant activity, many essential oils have shown antioxidant potential. As an example, there is the research conducted by Guimarães [35], who investigated the antioxidant activity of essential oils of Lippia sidoides, Alomia fastigiata, Ocotea odorifera, Mikania glauca and Cordia verbenacea, and their major constituents by the methods of the $\beta$-carotene/linoleic acid oxidation system, the formation of thiobarbituric acid reactive species (TBARS) and the reduction of the stable DPPH radical. The essential oil of Lippia sidoides showed higher antioxidant activity, presenting the lowest $\mathrm{IC}_{50}$ values in all trials. This activity was attributed to its major constituent carvacrol, which also showed high antioxidant activity when assessed in isolation [36].

The phenolic content in plants has been reported to be responsible for the antioxidant activity of some plants [37]. Phenolic compounds, like thymol and carvacrol, found in some plant essential oils, have been reported to have antioxidant activity [38]. Also essential oils rich in monoterpene hydrocarbons have been reported to have high antioxidant activity [39]. Ruberto and Baratta [40] investigated the antioxidant activity of 98 pure essential oil components, which represent the main classes of typical compounds of essential oils, and found out that sesquiterpene hydrocarbons exerted a low, if any, antioxidant effect.

The analysis of the essential oil components in this study revealed that the oils were mainly dominated by sesquiterpenes and non-terpenes. The poor antioxidant activity of these essential oils, probably, is due to their lack of phenolic compounds and low concentrations of monoterpene hydrocarbons. However, it has been observed that correlation of the antioxidant activities of essential oils and their chemical compositions is often very complicated [41]. Essential oil constituents acting individually or synergistically may contribute to the antioxidant activity of the oil [42]. 


\section{Conclusions}

Many papers on essential oils have been published, however the data showed much discordance between the same plant essences. The reasons for this variability can be understood, if we take into account all the factors influencing the chemical composition of the oils, namely, climatic, seasonal and geographic conditions, harvest period and extraction or distillation technique, among others. In this study, the dominant compounds in the essential oils in six tree parts of $C$. albidum were m-xylene $(66.7 \%$; seed), p-xylene (21.4\%; seed bark), $\alpha$-farnesene (38.1\%; leaf), hexadecanoic acid (14.7\%; stem bark), m-xylene (53.1\%; root bark) and hexadecanoic acid (12.7\%; fruit bark).

The results reported here can be considered as the first information on the chemical composition and the biological activity of the essential oil from the leaves, stem bark, seed, seed bark and fruit bark of Nigerian-grown C. albidum. This study has identified the antibacterial, antioxidant and insecticidal properties of the plant with a view to establish the pharmacological uses.

\section{Acknowledgments}

The authors are grateful to the Third World Academy of Science (TWAS) for the award which enhanced the completion of this research, as well as to Rida, Zunaira and Sheeba of Hussain Ebrahim Jamal (HEJ) Research Institute of Chemistry, University of Karachi, Pakistan for the antibacterial, antioxidant and insecticidal assay.

\section{References}

[1] Maedeh, M., Hamzeh, I., Hossein, D., Majid, A., and Reza, R. K. 2011. "Bioactivity of Essential Oil from Satureja hortensis (Laminaceae) against Three Stored-Product Insect Species." African J. Biotech. 10 (34): 6620-7.

[2] Buchbauer, G. 2000. "The Detailed Analysis of Essential Oils Leads to the Understanding of Their Properties." Perfumer and Flavorist 25: 64-7.

[3] Ehiagbonare, J. E., Onyibe, H. I., and Okoegwale, E. E.
2008. "Studies on the Isolation of Normal and Abnormal Seedlings of Chrysophyllum albidum: A Step towards Sustainable Management of the Taxon in the 21st Century." Sci. Res. Essay 3 (12): 567-70.

[4] Bada, S. O. 1997. "Preliminary Information on the Ecology of Chrysophyllum albidum G. Don in West and Central Africa." In Proceedings of National Workshop on the Potentials of Star Apple in Nigeria, 16-25.

[5] Keay, R. W. J. 1989. Trees of Nigeria. Oxford: Clarendon Press.

[6] Oboh, I. O., Aluyor, E. O., and Audu, T. O. K. 2009. "Use of Chrysophyllum albidum for the Removal of Metal Ions from Aqueous Solution.” Sci. Res. Essay 4 (6): 632-5.

[7] Okoli, B. J., and Okere, O. S. 2010. "Antimicrobial Activity of the Phytochemical Constituents of Chrysophyllum albidum G. Don Holl. (African Star Apple) Plant." J. Res. Nat. Dev. 8 (1): 301-11.

[8] Amusa, N. A., Ashaye, O. A., and Oladapo, M. O. 2003. "Biodeterioration of African Star Apple (Chrysophyllum albidum) in Storage and the Effect on Its Food Value." African J. Biotech. 2 (3): 56-9.

[9] Duyilemi, O. P., and Lawal, I. O. 2009. "Antibacterial Activity and Phytochemical Screening of Chrysophyllum albidum Leaves." Asian Journal of Food and Agro-Industry 2: 75-9.

[10] Ugbogu, O. C., and Akukwe, A. R. 2009. "The Antimicrobial Effect of Oils from Pentaclethra macrophylla Bent, Chrysophyllum albidum G. Don and Persea gratissima Gaerth F. on Some Local Clinical Bacteria Isolates." African J. Biotech. 8 (2): 285-7.

[11] Abiodun, A. H., Abolaji, A. O., Kela, R., Ayepola, O. O., Olorunfemi, T. B., and Taiwo, O. S. 2011. "Antioxidant Activities of the Leaves of Chrysophyllum albidum G.." Pak. J. Pharm. Sci. 24 (4): 545-51.

[12] Idowu, T. O., Iwalewa, E. O., Aderogba, M. A., Akinpelu, B. A., and Ogundaini, A. O. 2006. "Antinociceptive, Anti-inflammatory and Antioxidant Activities of Eleagnine: An Alkaloid Isolated from Seed Cotyledon of Chrysophyllum albidum.” J. Biol. Sci. 6 (6): 1029-34.

[13] Adisa, S. A. 2000. "Vitamin C, Protein and Mineral Content of African Star Apple (C. albidum)." In Proceeding of the 18th Annual Conference of National Institute of Science and Technology, 141-6.

[14] Adebayo, A. H., Abolaji, A. O., Opata, T. K., and Adegbenro, I. K. 2010. "Effects of Ethanolic Leaf Extract of Chrysophyllum albidum G. on Biochemical and Hematological Parameters of Albino Wistar Rats." African J. Biotech. 9 (14): 2145-50.

[15] Adewoye, E. O., Salami, A. T., and Emikpe, B. O. 2012. "Effect of Methanolic Extract of Chrysophyllum albidum Bark on Hematological Indices in Mice with 
Experimental Hemorrhagic Anemia.” African J. Biomed. Res. 15 (2): 85-91.

[16] Egunyomi, A. S., and Oladunjoye, S. 2012. "Studies on the Chemical Composition and Nutritive Value of the Fruit of African Star Apple.” African J. Agric. Res. 7 (31): 4256-88.

[17] Ajewole, K., and Adeyeye, A. 1991. "Seed Oil of White Star Apple (Chrysophyllum albidum): Physiochemical Characteristics and Fatty Acid Composition." J. Sci. Food Agric. 54 (2): 313-5.

[18] Moronkola, D. O. 2001. "Essential Oil from the Fruits of Six Nigerian Plants and Syntheses of Fragrant Terpenoids." Ph.D. thesis, Department of Chemistry, University of Ibadan, Nigeria.

[19] Moronkola, D. O., Oyedeji, O. A., Ekundayo, O., and Ogunbinu, O. A. 2006. "Composition of the Root Essential Oil of Chrysophyllum albidum G. Don." Bowen J. Agric. 3 (1): 53-8.

[20] Adams, R. P. 2007. Identification of Essential Oil Components by Gas Chromatography/ Mass Spectrometry, 4th ed.. Carol Stream, Illinois: Allured Publication Corporation.

[21] Joulain, D., and Koenig, W. A. 1998. The Atlas of Spectral Data of Sesquiterpene Hydrocarbons. Hamburg, Germany: EB-Verlag.

[22] National Institute of Standards and Technology (NIST). 2017. "NIST Chemistry Web Book." Data from NIST Standard Reference Database 69. Accessed June 21, 2017. http://webbook.nist.gov/chemistry/.

[23] Yamaguchi, T., Takamura, H., Matoba, T., and Terao, J. 1998. "HPLC Method for Evaluation of the Free Radical-Scavenging Activity of Foods by Using 1,1-Diphenyl-2-Picrylhydrazyl." Biosci. Biotech. Biochem. 62 (6): 1201-4.

[24] Tabassum, R., Naqvi, S. N. H., Azmi, M. A., Nurulain, S. M., and Khan, M. F. 1997. "Residual Effect of a Neem Fraction, Nimolicine and an Insect Growth Regulator, Dimilin, against Stored Grain Pest Callosobruchus analis." In Proceeding of the Pakistan Congress of Zoology, 165-70.

[25] Lee, B. H., Annis, P. C., and Tumaalii, F. 2003. "The Potential of 1,8-Cineole as a Fumigant for Stored Wheat." In Stored Grain in Australia, edited by Wright, E. J., Webb, M. C., and Highley, E. Canberra, Australia: CSIRO Stored Grain Research Laboratory, 230-4.

[26] Regnault-Roger, C., and Hamraoui, A. 1995. "Fumigant Toxic Activity and Reproductive Inhibition Induced by Monoterpenes on Aeanthoseelides obteetus (Say) (Coleoptera), a Bruchid of Kidney Bean (Phaseolus vulgaris L.)." J. Stored Products Res. 31 (4): 291-9.

[27] Ahn, Y. J., Lee, S. B., Lee, H. S., and Kim, G. H. 1998. "Insecticidal and Acaricidal Activity of Carvacrol and
Thujaplicine Derived from Thujopsis dolabrata var. Hondai Sawdust." J. Chem. Eco. 24 (1): 81-90.

[28] Isman, M. B. 2000. "Plant Essential Oils for Pest and Disease Management." Crop Protection 19: 603-8.

[29] Ebadollahi, A. 2011. "Iranian Plant Essential Oils as Sources of Natural Insecticide Agents." Int. J. Biol. Chem. 5 (5): 266-90.

[30] Lee, S., Peterson, C. J., and Coats, J. R. 2002. "Fumigation Toxicity of Monoterpenoids to Several Stored Product Insects.” J. Stored Product Res. 39 (1): 77-85.

[31] Papachristos, D. P., Karamanoli, K. I., Stamopoulos, D. C., and Menkissoglu-Spiroudi, U. 2004. "The Relationship between the Chemical Composition of Three Essential Oils and Their Insecticidal Activity against Acanthoscelides obtectus (Say).” Pest Management Sci. 60 (5): 514-20.

[32] Stamapoulos, D. C., Damos, P., and Karagianidou, G. 2007. "Bioactivity of Five Monoterpenoid Vapours to Tribolium confusum (du Val) (Coleoptera: Tenebrionidae)." J. Stored Product Res. 43 (4): 571-7.

[33] Mata, A. T., Proença, C., Ferreira, A. R., Serralheiro, M. L. M., Nogueira, J. M. F., and Araújo, M. E. M. 2007. "Antioxidant and Anti-acetylcholinesterase Activities of Five Plants Used as Portuguese Food Spices." Food Chem. 103 (3): 778-86.

[34] Viuda-Martos, M., Navajas, Y. R., Zapata, E. S., Fernández-López, J., and Pérez-Álvarez, J. A. 2009. "Antioxidant Activity of Essential Oils of Five Spice Plants Widely Used in a Mediterranean Diet." Flav. Frag. J. 25 (1): 13-9.

[35] Guimarães, L. G. L. 2010. "Essential Oil of Lippia sidoides Cham., Alomia fastigiata (Gardner) Benth, Ocotea odorifera (Vell.) Rohwer, Mikania glauca Mart. e Cordia verbenacea D.C.: Identification and Chemical Quantification, Characterization of the Secretory Structures, Antioxidant and Antibacterial Activities." Ph.D. thesis, Federal University of Lavras, Lavras, Brazil. (in Portuguese)

[36] Andrade, M. A., Cardoso, M., Andrade, J., Silva, L. F., Teixeira, M. L., Valério-Resende, J. M., Silva-Figueiredo, A. C., and Barroso, J. G. 2013. "Chemical Composition and Antioxidant Activity of Essential Oils from Cinnamodendron dinisii Schwacke and Siparuna guianensis Aublet." Antioxidants 2 (4): 384-97.

[37] Othman, A., Ismail, A., Abdul-Ghani, N., and Adenan, I. 2007. "Antioxidant Capacity and Phenolic Content of Cocoa Beans." Food Chem. 100 (4): 1523-30.

[38] Miguel, G., Simoes, M., Figueiredo, A. C., Barroso, J. G., Pedro, L. G., and Carvalho, L. 2004. "Composition and Antioxidant Activities of the Essential Oils of Thymus caespititius, Thymus camphoratus and Thymus mastichina." Food Chem. 86 (2): 183-8. 
Chrysophyllum albidum G. Don

[39] Tepe, B., Daferera, D., Sokmen, A., Sokmen, M., and Polissiou, M. 2005. "Antimicrobial and Antioxidant Activities of the Essential Oil and Various Extracts of Salvia tomentosa Miller (Lamiaceae)." Food Chem. 90 (3): $333-40$.

[40] Ruberto, G., and Baratta, M. T. 2000. "Antioxidant Activity of Selected Essential Oil Components in Two
Lipid Model Systems.” Food Chem. 69 (2): 167-74.

[41] Miguel, M. G. 2010. "Antioxidant and Anti-inflammatory Activities of Essential Oils: A Short Review." Molecule 15 (12): 9252-87.

[42] Tiwari, A. K. 2001. "Imbalance in Antioxidant Defence and Human Diseases: Multiple Approach of Natural Antioxidant Therapy." Curr. Sci. 81 (9): 1179-87. 